\title{
STUDI EFEKTIFITAS PERMA NOMOR 2 TAHUN 2008 TENTANG KOMPILASI HUKUM EKONOMI SYARIAH [KHES] SEBAGAI PEDOMAN DALAM PENYELESAIAN PERKARA EKONOMI SYARIAH DI PENGADILAN AGAMA
}

\author{
Darwin \\ Hakim Pengadilan Agama Kota Sawahlunto, Sumatera Barat
}

\begin{abstract}
This study was focused on the Rules of Supreme Courts (PERMA) Number 2/2008 about the Compilation of Islamic Economy Laws (KHES). The sudy was classified into qualitative approach. The finding revealed that PERMA Number 2/2008 about KHES was run effectively in religious court since September $10^{\text {th }}, 2008$.
\end{abstract}

Keywords: PERMA Number 2/2008, KHES, Religious Justice Court, Syariah Economy

\section{PENDAHULUAN}

Indonesia adalah negara hukum, sebagaimana ditegaskan dalam Pasal 1 Ayat (3) Undang-Undang Dasar 1945 (UUD 1945). Negara hukum pada prinsipnya menghendaki segala tindakan atau perbuatan penguasa mempunyai dasar hokum (Sutioso dan Puspitasari, 2005: 1). Azhary (2004: 205) mengatakan makna negara hukum adalah segala sesuatu harus ada tata cara dan harus memenuhi prosedur hukum. Dalam Penjelasan Pasal 1 Undang-Undang Nomor 12 Tahun 2011, tentang Pengganti Undang-Undang Nomor 10 Tahun 2004 tentang Pembentukan Peraturan Perundang-undangan, dijelaskan bahwa Indonesia sebagai Negara hukum, segala aspek kehidupan dalam bidang kemasyarakatan, kebangsaan, dan kenegaraan termasuk pemerintahan harus berdasarkan atas hukum, sesuai dengan sistem hukum nasional, sistem hukum nasioanal merupakan hukum yang berlaku di Indonesia dengan semua elemennya.

Dari uraian tersebut dapat dipahami bahwa Indonesia menganut konsep negara hukum, maka penyelenggara negara harus membentuk hukum dalam setiap aspek kehidupan bermasyarakat, berbangsa dan bernegara. Untuk dirasakan manfaat dan keguanaan hukum itu, tentu tidak berhenti di situ saja, harus ada penerapan hukum yang juga diatur oleh hukum, kalau tidak hukum itu hanya tinggal di atas kertas dan tidak dapat mengatur masyarakat dan Negara. Untuk berfungsinya hukum sebagai pengatur kehidupan manusia, menurut Satjipto Raharjo hukum itu harus 
menempuh proses pembuatan hukum dan penegakan hukum. Penegakan hukum tidak lain adalah penegakan peraturan perundang-undangan secara konkrit dalam kehidupan masyarakat (Raharjo, 1991: 175). Menurut Kansil (1986: 171) UUD hanyalah memuat ketentuan-ketentuan dasar dan merupakan rangka dari tata hukum Indonesia, masih banyak ketentuanketentuan yang perlu diselenggarakan lebih lanjut dalam berbagai undangundang organik.

Dari pendapat tersebut dapat dipahami bahwa implementasi Negara Hukum Indonesia adalah setiap penyelenggaraan Negara Indonesia harus berdasarkan peraturan perundang-undangan. Maka langkah utama pembentukan peraturan perundang-undangan yang diikuti dengan penegakannya. Di samping sebagai Negara Hukum, Indonesia juga Negara yang berdasarkan Ketuhanan Yang Maha Esa sebagaimana ditegaskan pada Pasal 29 Undang-Undang Dasar 1945. Karena itu, pembentukan peraturan perundangundangan harus menjadikan hukum yang bersumber dari agama sebagai bahan bakunya.

Konsep negara hukum menurut Sutioso dan Puspitasari (2005: 9) berkaitan dengan sistem hukum yang dianut negara yang bersangkutan. Selanjutnya menurut mereka, dalam literatur lama, sistem hukum di dunia ini ada dua, yaitu Anglo Saxon dan Eropa Kontinental. Dalam karya tulis yang datang kemudian menyebutkan ada sistem hukum selain itu yaitu sistem hukum Islam dan sistem hukum sosialis. Selanjutnya konsep negara hukum dilihat dari sudut pandang sejarah hukum yang berbeda antar negara-negara, menurut Azhary (2004: 7) ditemukan lima konsep negara hukum, yaitu Nomograsi Islam, Rechsstaat di Negara Eropa Kontinenntal seperti Belanda dan Jerman, Rule of law di Negara yang tidak mengutamakan perundang-undangan seperti Inggris dan Amerika Serikat, Sosialist Legalility di Negara komunis, dan konsep Negara Hukum Pancasila. Ciri khas negara hukum adalah pengakuan dan perlindungan atas hak asasi manusia, peradilan yang bebas dan legalitas dalam arti hukum dalam segala bentuknya.

Kajian efektifitas hukum dalam dunia ilmu hukum menurut Raharjo (1991: 253) adalah memahami tugas hukum dalam masyarakat, untuk itu perlu teori, namun dalam kenyataannya melahirkan aliran sosiologis yang di antara tokohnya adalah Roscou Pond mengatakan bahwa bagi para ahli hukum beraliran sosiologis, perlu lebih memperhitungkan fakta-fakta sosial dalam pekerjaannya baik dalam pembuatan 
hukum, penafsiran maupun penerapannya, ia harus lebih memperhitungkan secara pandai fakta sosial yang harus diserap dalam hukum dan nantinya akan menjadi sasaran penerapannya.

Tujuan efektifitas hukum adalah bagaimana hukum itu bekerja dalam masyarakat, sehingga hukum itu bermanfaat untuk mempengaruhi perilaku masyarakat. Efektifitas hukum sangat berkaitan dengan keberlakuan hukum dalam masyarakat dan bagaimana masyarakat mematuhi hukum, sehingga hukum itu bermanfaat dalam mempengaruhi perilaku masyarakat. Oleh karena itu efektifitas hukum berkaitan juga dengan dari mana hukum itu dibuat sera hubungannya dengan hukum yang hidup dalam masyarakat.

Penelitian hukum menurut Soekanto (2011: 13) memerlukan data sekunder (penelitian kepustakaan) dapat dikatakan penelitian hukum normatif di samping penelitian sosiologis. Karena penelitian hukum normatif mencakup asas hukum, sistematika hukum, taraf singkronisasi vertikal dan horizontal, perbandingan hukum dan sejarah hukum. Kajian tersebut tidak terlepas dari penelitian terhadap manusia, kebudayaan dan lingkungan yang menghasilkan tata hukum (tertulis) tertentu dan kaidah yang dirumuskan dalam perundang-undangan, serta hierarki perundang-undangan yang berlaku. Dalam buku lain Soekanto (1981: 51) mengatakan bahwa dalam penelitian hukum sosiologis adalah telaah terhadap identifikasi hukum (tidak tertulis) dan efektifitas hukum.

Penegakan hukum (law enforcement) menurut Sutioso dan Puspitasari (2005: 83) dapat dilakukan yang efektif merupakan salah satu tolok ukur keberhasilan suatu Negara dalam memberikan perlindungan hukum dan kepastian hukum bagi rakyat. Penegakan hukum pada dasarnya merupakan kesenjangan antara hukum secara normatif (das sollen) dan hukum secara sosiologis (das sein). Roscou Pound menyebutnya perbedaan antara "law in the book dan law in action" yang mencakup persoalan apakah hukum dalam bentuk peraturan yang telah diundangkan itu mengungkapkan pola tingkah laku sosial, apakah yang dikatakan pengadilan sama dengan yang dilakukan dan apakah tujuan yang secara tegas dikehendaki peraturan itu sama dengan efek peraturan itu dalam kenyataan.

Menurut pandangan aliran realism baru, salah satu penganutnya adalah ahli hukum Amerika Karl Llewellyn (1893-1962), mengatakan bahwa di antara pokok-pokok pendekatan kaum realis di antaranya hendaknya hukum itu dinilai dari efektifitasnya dan kemanfaatannya (Raharjo, 1991:301). Dari pendapat tersebut 
dapat dipahami bahwa penelitian efektifitas hukum dapat dilakukan dengan penelitian hukum normatif dan sosiologis.

\section{METODE PENELITIAN}

Penelitian ini adalah penelitian deskriptif dengan pendekatan kualitatif yang dilakukan dengan mendeskripsikan bagaimana efektifitas PERMA Nomor 2 Tahun 2008 tentang Kompilasi Hukum Ekonomi Syariah (KHES) sebagai Pedoman dalam Penyelesaian Perkara Ekonomi Syariah di Pengadilan Agama berdasarkan teori yang digunakan. Instumen penelitian yang digunakan dalam penelitian ini adalah wawancara, observasi dan dokumentasi.

Teknik observasi yang digunakan dalam penelitian ini untuk menggali data dari sumber data yang berupa peristiwa, tempat atau lokasi dan benda serta rekaman gambar (Sutopo, 2002: 64). Teknik wawancara yang digunakan dalam penelitian ini adalah teknik wawancara tidak terstruktur (indepth interviewing) karena peneliti merasa "tidak tahu apa yang belum diketahuinya". Dengan demikian wawancara dilakukan dengan pertanyaan yang bersifat "openended", dan mengarah kepada kedalaman informasi (Sutopo, 2002: 59) dari data primer. Studi dokumen dilakukan dengan penelitian mengenai dokumen-dokumen yang berkaitan dengan efektifitas PERMA
Nomor 2 Tahun 2008 tentang Kompilasi Hukum Ekonomi Syariah (KHES) sebagai Pedoman dalam Penyelesaian Perkara Ekonomi Syariah di Pengadilan Agama. Dokumen sudah lama digunakan dalam penelitian sebagai sumber data karena dalam banyak hal dokumen sebagai sumber data dimanfaatkan untuk menguji, menafsirkan, bahkan untuk meramalkan (Moleong, 2007: 217).

Analisis data pada penelitian ini dilakukan secara kualitatif, yaitu dari data yang diperoleh kemudian disusun secara sistematis kemudian dianalisis secara kualitatif untuk mencapai kejelasan masalah yang dibahas. Analisis data kualitatif adalah suatu cara penelitian yang menghasilkan data deskriptif, yaitu apa yang dinyatakan oleh responden secara tertulis atau lisan dan juga perilakunya yang nyata diteliti dan dipelajari sebagai sesuatu yang utuh. Teknik pengolahan data dilakukan dengan (1) mereduksi data yang meliputi mengumpulkan dan menghimpun sumber-sumber data terkait melalui wawancara dengan sumber data menggunakan media tulis, mencatat kembali hasil wawancara untuk kemudian ditranskripkan menggunakan bahasa yang tepat dan benar; (2) memaparkan atau menyajikan data dalam bentuk naratif; dan (3) menarik kesimpulan. 


\section{HASIL PENELITIAN DAN PEMBAHASAN}

Berdasarkan penelitian yang dilakukan, peneliti memperoleh temuan bahwa PERMA Nomor 2 Tahun 2008 tentang KHES telah berlaku efektif sebagai pedoman dalam penyelesaian perkara ekonomi syariah di Pengadilan Agama. Karena PERMA mempunyai nilai guna dan hasil guna sejak diberlakukannya pada tanggal 10September 2008. Walaupun efektifitasnya belum sepenuhnya karena masih ada hakim yang kurang memahami dan menerapkannya, disebabkan adanya faktor ketidakjelasan rumusan kalimat dalam peraturannya dan tidak diundangkannya dalam Berita Negara Republik Indonesia.

PERMA merupakan singkatan dari Peraturan Mahkamah Agung, yang dibentuk dan ditetapkan oleh Ketua mahkamah Agung Republik Indonesia. Namun karena yang diberlakukan adalah KHES, materi muatannya adalah Hukum Syariah, maka perlu disinggung landasan yuridis formal syariah dalam kerangka hukum berdasarkan Pancasila.

Menurut Penjelasan Pasal 2 UndangUndang Nomor 12 Tahun 2011 tentang Pembentukan Peraturan Perundangundangan, Penempatan Pancasila sebagai sumber dari segala sumber hukum adalah sesuai dengan Pembukaan UUD 1945 alinea keempat yaitu Ketuhanan Yang Maha Esa, kemanusiaan yang adil dan beradab, persatuan Indonesia, kerakyatan yang dipimpin oleh hikmat kebijaksanaan permusyawaratan/perwakilan, dan keadilan sosial bagi seluruh rakyat Indonesia. Menempatkan Pancasila sebagai dasar dan ideologi negara serta sekaligus dasar filosofi negara sehingga setiap materi muatan peraturan perundang-undangan tidak boleh bertentangan dengan nilai-nilai yang terkandung dalam Pancasila.

Maka pembentukan PERMA Nomor 2 Tahun 2008 tentang KHES yang berasal dari nilai-nilai hukum syariah sesuai dengan indikator yang dikemukakan oleh Garuda Wiko, bahwa menyangkut tentang hukumnya, pembentukan hukum positif untuk membangun sistem hukum nasional yang dapat mengembalikan jati diri bangsa, harus dikaji dengan mengoreksi elemen sistem hukum dan pemikiran Eropa sebagai pembanding dan diuji dengan cita-cita konstitusi dan keadilan sosial yang berakar pada kolektifitas.

Pembentukan PERMA Nomor 2 Tahun 2008 tentang KHES sebagai aplikasi dari teori "Lingkaran Konsentris" yang dikemukakan oleh Tahir Azhary yang menunjukkan betapa eratnya hubungan agama, hukum dan Negara. Sebagaimana dikatakan oleh Ichtijanto SA bahwa teori 
tersebut dapat dijadikan landasan di masa mendatang, dan teori tersebut berpangkal dari teori yang dikemukakan oleh Friederik Julius Stahl dan Hazairin.

Landasan yuridis formal bagi Mahkamah Agung untuk menyusun dan membentuk PERMA Nomor 2 Tahun 2008 tentang KHES, adalah berdasarkan Pasal 24 UUD 1945, yaitu menyelenggarakan kekuasaan kehakiman guna menegakkan hukum dan keadilan. Pasal 24A ayat (1) UUD 1945, menegaskan bahwa Mahkamah Agung mengadili pada tingkat kasasi, menguji peraturan perundang-undangan di bawah undang-undang terhadap undangundang dan kewenangan lainnya yang diberikan undang-undang.

Maka amanat Pasal 24 dan Pasal 24A UUD 1945 tersebut dilaksanakan dan dipertegas oleh Undang-Undang Nomor 48 2009 tentang Kekuasaan Kehakiman, Pasal 20 ayat (1), menegaskan bahwa Mahkamah Agung merupakan pengadilan Negara tertinggi dari badan peradilan yang berada di dalam empat lingkungan peradilan. Secara rinci kewenangan Mahkamah Agung disebutkan pada ayat (2), yaitu sebagai berikut.

1. Mengadili pada tingkat kasasi terhadap putusan terakhir oleh pengadilan;
2. Menguji peraturan perundangundangan di bawah undang-undang terhadap undang-undang; dan

3. Kewenangan lainnya yang diberikan undang-undang.

Mengenai kewenangan lainnya itu, diperjelas oleh Undang- Undang Nomor 14 Tahun 1985 tentang Mahkamah Agung, yang telah dirubah dengan UndangUndang Nomor 5 Tahun 2004 terakhir dengan Undang Nomor 3 Tahun 2009, pada Pasal 32, disebutkan:

1. Mahkamah Agung melakukan pengawasan tertinggi terhadap penyelenggaraan peradilan pada semua badan peradilan;

2. Mahkamah Agung melakukan pengawasan tertinggi terhadap pelaksaan tugas administrasi dan keuangan;

3. Mahkamah Agung berwenang memita keterangan teknis peradilan;

4. Mahkamah Agung berwenang memberi petunjuk, teguran, atau peringatan kepada peradilan; dan

5. Kewenangan dan pengawasan tersebut tidak boleh mengurangi kebebasan hakim dalam memeriksa dan memutus perkara. 
Dalam Pasal 79 Undang-Undang Nomor 14 Tahun 1985 tentang Mahkamah Agung, ditetapkan bahwa Mahkamah Agung dapat mengatur lebih lanjut hal-hal yang diperlukan bagi kelancaran penyelenggaraan peradilan apabila terdapat hal-hal yang belum cukup diatur dalam undang-undang ini. Karenanya selama hal-hal tersebut belum diatur oleh undang-undang dan diatur oleh Mahkamah Agung, maka aturan Mahkamah Agung tersebut sifatnya permanen.

Dalam penjelasan Pasal 79 tersebut disebutkan, apabila terdapat kekurangan atau kekosongan hukum tentang suatu hal dalam jalannya peradilan, Mahkamah Agung berwenang membuat peraturan sebagai pelengkap untuk mengisi kekurangan atau kekosongan itu, yaitu tentang cara penyelesaian suatu soal yang belum atau tidak diatur oleh undang-undang. Pengaturan tersebut menyangkut bagian dari hukum acara secara keseluruhan. Mahkamah Agung tidak mencampuri hak dan kewajiban warga Negara, tidak pula mengatur sifat, kekuatan, alat pembuktian serta penilaian ataupun pembagian beban pembuktian.

Menurut Muhammad Yasin, kewenangan Mahkamah Agung yang diberikan Undang-Undang adalah sebagai berikut.
1. Memberikan pertimbangan hukum kepada Presiden dalam permohonan grasi dan rehabilitasi (Pasal 14 ayat 1 UUD jo Pasal 35 UUMA).

2. Memberikan pertimbangan dalam bidang hukum baik diminta maupun tidak kepada lembaga tinggi negara yang lain (Pasal 37 UUMA).

3. Memberikan petunjuk di semua lingkungan peradilan dalam rangka pelaksanaan ketentuan UU Kekuasaan Kehakiman (Pasal 38 UUMA).

4. Memberikan petunjuk, teguran, atau peringatan yang dipandang perlu kepada pengadilan di semua lingkungan peradilan.

Dalam literatur kewenangan dan tugas demikian disebut sebagai fungsi pengaturan atau regelende functie MA, sesuai rumusan Pasal 79 UUMA, maka produk hukum MA berupa Peraturan Mahkamah Agung (PERMA), Surat Edaran Mahkamah Agung (SEMA), Fatwa, dan Surat Keputusan Mahkamah Agung (SK KMA).

Untuk menganalisis bagaimana kedudukan PERMA Nomor 2 Tahun 2008 tentang KHES dalam Peraturan Perundangundangan, harus dipahami dulu apa yang dimaksud dengan peraturan perundangundangan. Berdasarkan Pasal 1 angka 2 
Undang-Undang Nomor 12 Tahun 2011 tentang Pengganti atas Undang-Undang Nomor 10 Tahun 2004 tentang Pembentukan Peraturan Perundang-Undangan, peraturan perundang-undangan adalah peraturan tertulis yang memuat norma hukum yang mengikat secara umum dan dibentuk atau ditetapkan oleh lembaga negara atau pejabat yang berwenang melalui prosedur yang ditetapkan dalam Peraturan Perundang-undangan.

Dari ketentuan tersebut ada tiga unsur yang harus dipenuhi dalam suatu peraturan supaya dapat dikatakan sebagai peraturan perundang-undangan, yaitu peraturan tertulis yang memuat norma hukum mengikat secara umum, dibentuk oleh lembaga negara atau pejabat yang berwenang dan pembentukannya melalui prosedur yang ditetapkan oleh peraturan perundang-undangan.

\section{KESIMPULAN}

Berdasarkan penelitian yang dilakukan, peneliti memperoleh kesimpulan bahwa PERMA Nomor 2 Tahun 2008 tentang KHES telah berlaku efektif sebagai pedoman dalam penyelesaian perkara ekonomi syariah di Pengadilan Agama. Karena PERMA tersebut mempunyai nilai guna dan hasil guna sejak diberlakukannya pada tanggal 10 September 2008.

\section{KEPUSTAKAAN ACUAN}

Azhary, Muhammad Tahir. (2004). Negara Hukum Suatu Studi tentang Prinsipprinsipnya Dilihat dari Segi Hukum Islam, Implementasinya pada Priode Negara Madinah dan Masa Kini. Jakarta: Prenada Media

Kansil, C.S.T. (1986). Pengantar Ilmu Hukum dan Tata Hukum Indonesia. Jakarta: Balai Pustaka

Moleong, Lexy, J, (2007). Metodologi Penelitian Kualitatif. Bandung: PT. Remaja Rosdakarya

Raharjo, Satjipto (1991). Ilmu Hukum. Bandung: PT. Citra Aditya Bakti

Soekanto, Soerjono. (2011). Penelitian Hukum Normatif Suatu Tunjauan Singkat. Jakarta: Raja Grapindo Persada

_(1981). Pengatar Penelitian Hukum. Jakarta: UI Pres

Sutioso, Bambang dan Puspitasari, Sri Hastuti. (2005). Aspek-Aspek Perkembangan Kekuasaan Kehakiman Di Indonesia. Yogyakarta: UII Press Sutopo, HB. (2002). Metodologi Penelitian Kualitatif. Surakarta: UNS Press 